INTERDISCIPLINARIA ARCHAEOLOGICA NATURAL SCIENCES IN ARCHAEOLOGY

\title{
Acorns as a Food Resource. An Experiment with Acorn Preparation and Taste
}

\author{
Tereza Šálkováa ${ }^{*}$, Michaela Divišováa , Štěpánka Kadochovác, Jiř́i Beneš ${ }^{b}$, Kateřina Delawskáa , Eva \\ Kadlčkováa, Lenka Němečkováa, Kamila Pokornáb, Václav Voska ${ }^{a}$, Andrea Žemličkováb \\ ${ }^{a}$ University of South Bohemia, Laboratory of Archaeobotany and Palaeoecology, Faculty of Science, Branišovská 31 , 37005 České Budějovice, \\ Czech Republic \\ ${ }^{b}$ University of South Bohemia, Department of archaeology, Faculty of Philosophy, Branišovská 31, 37005 České Budějovice, Czech Republic \\ ${ }^{c}$ Charles University, Department of Ecology, Faculty of Science, Viničná 7, 128 44, Prague 2, Czech Republic
}

\section{ARTICLE INFO}

\section{Article history:}

Received: 30 November 2011

Accepted: 20. December 2012

\section{Key words:}

acorns

prehistory

taste experiment

statistics

\begin{abstract}
A BS TRACT
This paper summarizes our current knowledge of acorns as a food resource in prehistoric Europe. It sheds light on the question of the taste of acorn products, which is closely linked to preparation methods. An experiment was conducted that consisted of the preparation of eight different acorn recipes, human tasters, a questionnaire-based survey, and statistical evaluation. The paper presents the various factors that testers indicated had an effect on the taste of differently prepared acorn products.
\end{abstract}

\section{Introduction}

Although oaks formed a significant component of European prehistoric landscape, their potential as a food resource has been underestimated relative to other plant foods. In spite of their characteristic taste, acorns have always been an attractive food resource, and exploited by humans. This contribution considers acorns and their importance in human diet throughout European prehistory. Additionally, the paper examines some methods of acorn processing and how various factors affect the taste of acorn products.

\subsection{Oaks}

From the beginning of the Holocene oak trees were an important element of the vegetation of much of Europe (Pokorný 2004; Dreslerová et al. 2007; Kuneš 2008). The common presence of oaks in forests throughout prehistory is evidenced by the numerous charcoal fragments found within the archaeological record of most prehistoric cultures (Vencl 1985, 535). In the Boreal period (Mesolithic, 11,500-8,900 BP), mixed oak forests (Quercetum mixtum) increasingly dominated the forest landscape. Mixed forests expanded from

${ }^{*}$ Corresponding author. E-mail: TerezaSalkova@seznam.cz the floodplains into their current range and then gradually transformed to acidophilous oak forests. A new type of forest, in which beech and fir were the dominant species, spread and became dominant in the Subboreal period (Eneolithic early Iron Age, 5700-2600 BP). However, the process of the degradation of mixed oak forest and the spread of modern forest communities was asynchronous (Dreslerová et al. 2007, 41-44).

Apart from acorns for food, oaks were exploited for numerous other purposes, including construction material, charcoal production, firewood, production of rope, and the extraction of tannin (Rosenberg 2008, 169). The use of oak (along with hazel, elm, ash, linden, willow, maple, alder and fir) as fire wood in winter during early prehistoric agricultural development was also of crucial importance (Dreslerová et al. 2007, 48).

\subsection{Acorns as a food resource}

Acorns are nutritionally comparable to cereals, being largely a source of carbohydrates, fats and fibres. Acorn also contains proteins, amino acids and vitamins, mostly A and C (Rosenberg 2008). The caloric value of acorn varies between species, but ranges between 265 and 520 calories per $100 \mathrm{~g}$ (see Rosenberg 2008). Additionally it has been proven that acorns have antioxidant effects (Rakić et al. 2006). In the 
right conditions acorns may also be stored for long periods (Mason 1995; Cunningham 2011).

On the other hand, acorns also contain a high concentration of tannic acid, a mild toxin which gives them a bitter taste. The concentration of tannin varies between oak species and even between individual trees of one species (Mason 1995). Some oak species produce acorns low in tannin and all acorns are edible when properly prepared. Tannins can be removed by a variety of methods such as soaking in water, boiling, roasting or even simply burying them in the ground (see Vencl 1985 for further details).

Vencl (1996) notes several factors limiting the exploitation of acorns as food. First, individual oak species differ in their annual fruit production and acorn taste. Oak begins to bear fruit after about 25 years. Even though oak trees usually produce a plentiful crop of acorns, a rich crop does not occur annually, and the interval between good yields varies by species. Although this irregularity of availability could be compensated by the durability of acorns and the coexistence of diverse oak species within one area, it can be assumed that this was a factor that limited oak cultivation (Vencl 1996, 95). Both good and poor producers tend to be similarly represented in the fruiting population (Greenberg 2000). With regard to central European oaks (Q. robur and Q. petraea), which go through a 2 to 6 year cycle, Karg and Haas have suggested that these could have been managed in prehistory in order to increase the availability of nutrient resources and consequently to enlarge the yields (Karg, Haas 1996). Another factor limiting acorn exploitation for food includes the amount of work involved in preparation.

Acorns were also exploited by past communities for many other reasons. They were consumed in the form of bread, soups, porridge, or as a coffee substitute right up to modern times (Rakić et al. 2006). Since acorns are also a source of food for many domestic animal species, the occurrence of acorns in archaeological contexts may result from their use as livestock fodder (Vencl 1996, 96-97). The use of acorrns for pig food has also been well documented since medieval times (Le Goff 1991). It should also be mentioned that acorns could be used for the processing of animal hides or dyeing (Vencl 1985). With respect to medicine it has been reported that oak acorns can be used to reduce urination, treat wound and inflammation, stop bleeding and to treat kidney stones (Lev, Amar 2000; Lev 2002).

\subsection{Acorns in prehistory}

In evaluating the evidence for acorn use by ancient communities, we need to consider several issues. First, one should bear in mind that the recovery of plant remains depends on harvesting and processing methods, preservation conditions, and method of retrieval (Dennel 1976). In the case of acorns, poor preservation results from certain processing techniques, due to carbonization which usually destroys the thin-walled shells (Lev et al. 2005). Additionally, the manner and location of acorn processing may have been undertaken completely or partially off site (Lev et al. 2005). Moreover, a limited use of flotation techniques in Europe and significant national and regional differences in the intensity of archaeobotanical research (Vencl 1985; Mason 1995), result in an underestimation of acorns as a source of human nutrition in the past. On the other hand, it needs to be stressed that recent research has put acorns as food into a new perspective. Currently, there is no doubt about the extensive use of acorns as food in prehistory (e.g. Vencl 1985; 1996; Mason 1992; 1995; Karg, Haas 1996; Kubiak-Martens 1999; Bouby et al. 1999; Lev et al. 2005).

To summarize, acorns are a food resource that could have played an important role in prehistoric human subsistence in Europe. As already stated, finds of charred acorns are not exceptional, and occur from the Mesolithic through to modern times throughout Europe. A considerable body of research indicates that acorns were used both occasionally in emergencies and systemically. The archaeological record, however, does not resolve whether the individual acorn finds represent a staple or sporadic food resource (Vencl 1985, 552). Acorn use has been widely investigated ethnographically, including a well-known ethnographic study of acorns use for human consumption in prehistoric California (e.g. Mason 1992). Aside from ethnographic research, finds of charred acorns in archaeological contexts have been examined and discussed by several authors (see for instance Vencl 1985, 1996; Mason 1992; De Hingh 2000).

Although plant remains are scare in the Palaeolithic, the oldest acorns have been found in a number of Palaeolithic sites in the Near East (e.g. Kislev et al. 1992; Goren-Inbar et al. 2002; Aura et al. 2005; Lev et al. 2005). In light of this, it is thought that acorns may have been a staple plant food long before the maximal spread of oak that occurred during the Atlantic period (late Mesolithic and Neolithic, 8900-5700 BP) (Vencl 1996, 100).

During the Mesolithic, finds of concentrations of charred acorns increase (Zvelebil 1994; Vencl 1996; KubiakMartens 1999; Aura et al. 2005), in accord with the spread of oak forests, which enabled intensive acorn gathering. Mason (2000) considered the possible role played by fire in the Mesolithic, and from ethnographic and ecological data suggested that fire could have been used to manipulate the acorn supply. This approach to Mesolithic forest burning challenges the traditional view that fire might have been used mainly to improve hunting by improving the productivity and nutritional quality of animal forage, or to attract animals or to improve visibility of animals by reducing their cover (Mason 2000, 139-140). Mason focuses on the manner in which burning contributes to acorn gathering. She posits that burning reduces competition for nutrients etc. from other species, and in so doing provides oak trees with advantages that improve the growth of acorns. In addition, removing ground cover facilitates gathering of acorns.

It should be clear at this point that during the pre-agricultural period acorns were an important plant food resource for hunter-gatherers in Europe. One should also bear in mind that archaeological evidence supports the conclusion that acorns have always been an attractive food resource within various resource strategies, including agrarian societies. 
According to De Hing $(2000,200-202)$ acorns in prehistoric agricultural communities may have played a role as food substitute or reserve for bad times, reserved for emergencies, for example when cereal agriculture had failed.

Within the context of agricultural sites acorns are usually located close to fireplaces and in furnaces. Frequently they are accompanied by other crops (De Hingh 2000). In addition, acorns are common finds in vessels and storage pits. They are often shelled and mixed with cereals. Acorns also occur in shallow pits and are also found unshelled (Deforce et al. 2009). Acorns are found in graves, and their appearance there as sacrificial offering cannot be discounted. (Vencl 1985).

There is no doubt that there is sufficient evidence for acorn use in human subsistence in prehistory, as shown above. The focus of this article is on the way in which acorns may have been processed to remove their tannins when using them for food. In order to do so we conducted an experiment, described below, the aim of which was to identify how preparation methods affect the final taste of the product.

\section{Materials and Methods}

\subsection{Experiment}

For our experiment we chose acorns from Quercus robur, which has grown throughout Europe since the beginning of the Holocene. Q. robur is also reported to have acorns which are relatively low in tannin. This species is a convenient nutritional resource (Rakić et al. 2006). Acorns were collected from several different locations in the region (Figure 1) between September and November 2011.

Acorns from each site were processed according to the following four methods. Subsequent processing include shelling, grinding, roasting and boiling, in various orders, using a modern knife, poppy seed grinder, pan, electric cooker and oven (Table 1).

Figure 1. Acorn collection sites, South Bohemia: 1 - Chotýčany, 2 - Stř́ibřec, 3 Hajská-Strakonice, 4+5 České BudějoviceStromovka; 6+7 - České Budějovice-U Lesa, 8 - Bechyně, 11 - Hartmanice.
Table 1. Characteristics of eight acorn product samples.

\begin{tabular}{|c|c|}
\hline Sample 1 & $\begin{array}{l}\text { 1. } \text { shelling } \\
\text { 2. grinding } \\
\text { 3. roasting to lose bitterness }\end{array}$ \\
\hline Sample 1A & $\begin{array}{l}\text { 1. shelling } \\
\text { 2. grinding } \\
\text { 3. roasting to loose bitterness } \\
\text { 4. mixing at } 1: 1 \text { ratio with wheat flour } \\
\text { (Triticum aestivum) }\end{array}$ \\
\hline Sample 2 & $\begin{array}{l}\text { 1. shelling } \\
\text { 2. boiling in water until soft } \\
\text { 3. grinding }\end{array}$ \\
\hline Sample 2A & $\begin{array}{l}\text { 1. shelling } \\
\text { 2. boiling in water until soft } \\
\text { 3. grinding } \\
\text { 4. mixing at 1:1 ratio with wheat flour } \\
\text { (Triticum aestivum) }\end{array}$ \\
\hline Sample 3 & $\begin{array}{l}\text { 1. } \text { roasting } \\
\text { 2. shelling } \\
\text { 3. } \text { grinding }\end{array}$ \\
\hline Sample 3A & $\begin{array}{l}\text { 1. roasting } \\
\text { 2. shelling } \\
\text { 3. grinding } \\
\text { 4. mixing at } 1: 1 \text { ratio with wheat flour } \\
\text { (Triticum aestivum) }\end{array}$ \\
\hline Sample 4 & $\begin{array}{l}\text { 1. } \text { shelling } \\
\text { 2. } \text { roasting } \\
\text { 3. boiling } \\
\text { 4. } \text { grinding }\end{array}$ \\
\hline Sample 4A & $\begin{array}{l}\text { 1. shelling } \\
\text { 2. roasting } \\
\text { 3. boiling } \\
\text { 4. grinding } \\
\text { 5. mixing at } 1: 1 \text { ratio with wheat flour } \\
\text { (Triticum aestivum) }\end{array}$ \\
\hline
\end{tabular}

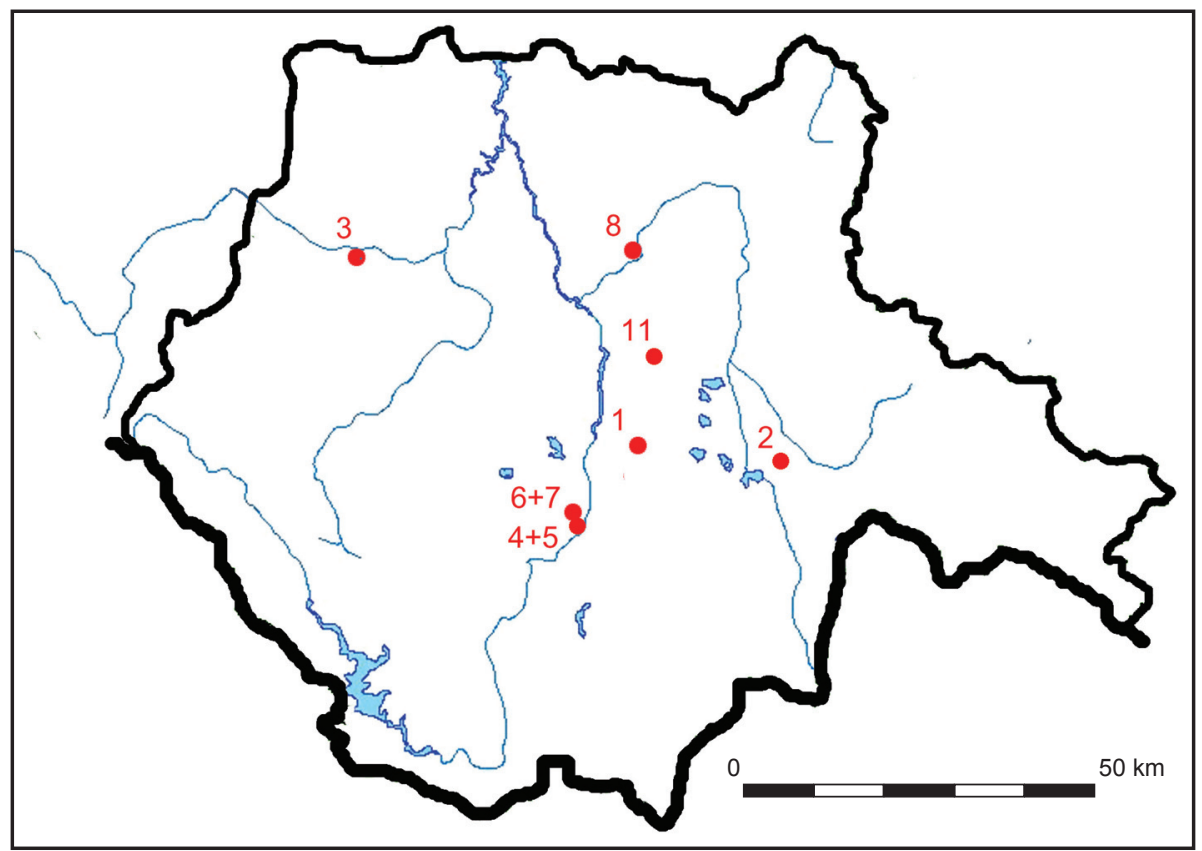


The resulting acorn and mixed acorn/wheat flour was mixed with salt, yeast and water, and baked in an electric oven into eight biscuit types.

\subsection{Questionnaire}

We expected that the taste of the biscuits would vary depending on the preparation method. It was therefore important that the causes of that variation should be understood. A way of approaching this problem is to use a questionnaire. A short questionnaire was used to assess both the characteristics of respondents (sex, and field of study in the case of archaeologists and biologists) and to rate the taste of each of the eight types. The latter was rated on a scale of 1 to 7: "excellent" to "disgusting". The questionnaire was completed by a population characterized in Table 2, including members of the public from of the Czech Republic (particularly southern Bohemia) and students attending the University of South Bohemia in České Budějovice.

Table 2. Characteristics of respondents; number of respondents: 282.

\begin{tabular}{lc}
\hline \multicolumn{2}{c}{ Characteristics of respondents } \\
\hline Sex & 168 \\
\hline Women & 114 \\
Men & \\
\hline Professional specialization & 35 \\
\hline Archaeologists & 90 \\
Biologists & 161 \\
Other & \\
\hline
\end{tabular}

The first aim was to show that variously prepared acorn products taste differently and to find which biscuit tastes the best. Samples 1, 2, 3 and 4 were assessed separately from 1A, 2A, 3A and 4A since we expected the latter would taste better due to the added wheat flour. The second aim was to test whether differences in taste were related to acorn source and/ or to the baker. The third aim was to test whether differences in taste relate to differences in the sample population, such as gender, field of study, etc.

\subsection{Statistics}

Data from the written questionnaires were transfered to an MS:Excel spreadsheet. MS:Excel was used for basic data manipulation (grouping the data according to treatment, respondent characteristics and other variables, calculating means, scores for individual treatments, making summary graphs, etc.). For further statistical analysis InStat GraphPad (version 3.00) was used.

First, we tested whether the preparation procedure and recipe had any effect on taste. To test the possible differences among acorn biscuit samples we conducted a one-way ANOVA analysis. The results showed highly significant differences among samples, however they revealed nonnormal distribution. Using Kolmogorov and Smirnov method all sample scores failed to pass normality test $(\mathrm{p}<0.001)$. Thus we decided to use non-parametric tests instead.
We assumed that the taste score for all samples would be subjective, i.e., one respondent would have a similar opinion of the taste of all eight samples. Data for the acorn biscuit samples would not be independent, and we therefore chose paired Friedman Test (Nonparametric Repeated Measures ANOVA).

For this analysis we distinguish 8 acorn products (see table above), four with acorn and four with acorn and wheat. Taste scores were not balanced across the samples, so for analytical purposes we replaced missing values (taste score) in some samples by the mean taste value counted for this sample group to achieve the same number of observations. We replaced missing values only if one score of eight was missing for a given respondent. If more values were missing the data from that respondent were removed from the analysis. To test whether the replacement of missing values with a mean had any effect on our results we also conducted another statistical analysis, where the 30 questionnaires with one missing score were eliminated from analysis. Again we considered our data to be non-normal and used a nonparametric paired Friedman Test. The results were very similar to those reached with the 30 partially incomplete questionnaires included. Therefore we assumed that the replacement of missing data had no detrimental effect, and we decided to use the full sample set to present our results, since it includes more experimental data and covers more variability.

We also sought to assess possible differences in biscuit taste related to acorn source and differences amongst respondents. As previous statistical analysis revealed significant differences in the taste of the biscuits, we conducted an assessment of other effects separately for each sample, using Multiple Regression. The tested model was "sample taste $\sim$ group + respondent + sex + field of interest". Because each sample was evaluated separately, we did not need to do any correction for the unequal number of sample taste scores.

\section{Results}

\subsection{Effect of preparation method on biscuit taste}

The taste of baked acorn products prepared with different processing methods (samples 1, 2, 3, 4) do not significantly differ among each other (paired Friedman Test, $\mathrm{p}>0.05$ ). Interestingly, some respondents did note a taste difference among biscuits with wheat flour. This difference is only valid for comparison of 1A-2A, 1A-4A and 3A-4A samples. Sample 1A-4A shows the most significant difference $(\mathrm{p}<001)$. Comparison of $2 \mathrm{~A}-3 \mathrm{~A}$ does not show significant differences. We can assume that procedure 1 has an effect on the taste properties. This effect, however, is noted only after the addition of wheat flour.

The taste of purely acorn products significantly differs from all products with added wheat flour. The results indicate that the taste of acorn biscuits is noticeably different from taste of acorn/wheat biscuits. 


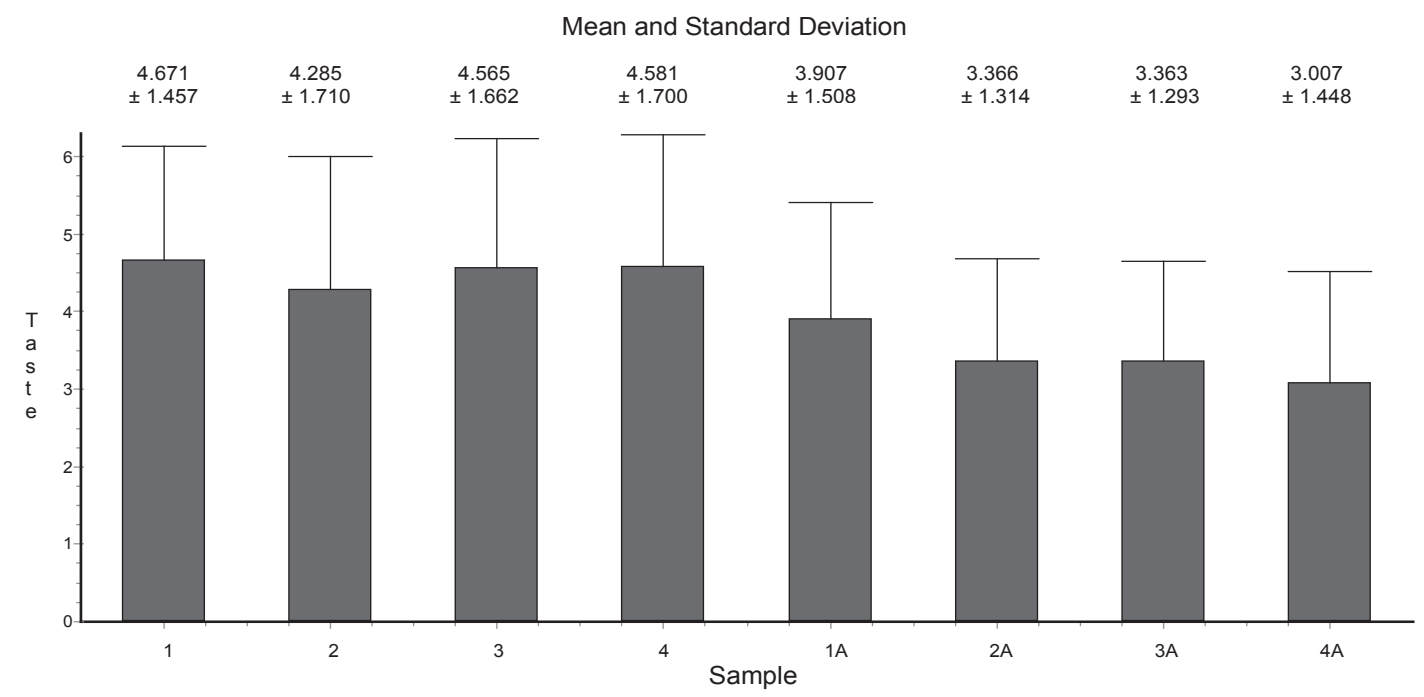

Figure 2. Comparison of individual preparation methods, mean taste $\pm \mathrm{SD}$ (compared on scale from 1 to 7), Paired Friedman Test, $\mathrm{p}<0.001$. Note that increasing value on taste scale means less tasty products, the scale goes from 1 as "excellent" to 7 as "disgusting".

Table 3. The differences observed among all biscuit samples according to preparation method; paired Friedman Test, significance levels are marked as follows: $\mathrm{NS}=$ non significant, $*=\mathrm{p}<0.05, * *=\mathrm{p}<0.01, * * *=\mathrm{p}<0.001$.

\begin{tabular}{ccccccccc}
\hline Sample & $\mathbf{1}$ & $\mathbf{1 A}$ & $\mathbf{2}$ & $\mathbf{2 A}$ & $\mathbf{3}$ & $\mathbf{3 A}$ & $\mathbf{4}$ & $\mathbf{4 A}$ \\
\hline 1 & - & $* * *$ & $\mathrm{~ns}$ & $* * *$ & $\mathrm{~ns}$ & $* * *$ & $\mathrm{~ns}$ & $* * *$ \\
$1 \mathrm{~A}$ & $* * *$ & - & $\mathrm{ns}$ & $*$ & $* * *$ & $\mathrm{na}$ & $* * *$ & $* * *$ \\
2 & $\mathrm{~ns}$ & $\mathrm{~ns}$ & - & $* * *$ & $\mathrm{~ns}$ & $* * *$ & $\mathrm{~ns}$ & $* * *$ \\
$2 \mathrm{~A}$ & $* * *$ & $*$ & $* * *$ & - & $* * *$ & $\mathrm{~ns}$ & $* * *$ & $\mathrm{~ns}$ \\
3 & $\mathrm{~ns}$ & $* * *$ & $\mathrm{~ns}$ & $* * *$ & - & $* * *$ & $\mathrm{~ns}$ & $* * *$ \\
$3 \mathrm{~A}$ & $* * *$ & $\mathrm{~ns}$ & $* * *$ & $\mathrm{~ns}$ & $* * *$ & - & $* * *$ & $*$ \\
4 & $\mathrm{~ns}$ & $* * *$ & $\mathrm{~ns}$ & $* * *$ & $\mathrm{~ns}$ & $* * *$ & - & $* * *$ \\
$4 \mathrm{~A}$ & $* * *$ & $* * *$ & $* * *$ & $\mathrm{~ns}$ & $* * *$ & $*$ & $* * *$ & - \\
\hline
\end{tabular}

Table 4. Summarize table. Total number of respondents' evaluation taste scores for individual acorn biscuit samples (counted from all data except of respondents 3, 34, 150-158 who were excluded because of more than 1 missing value in scoring).

\begin{tabular}{lccccccccc}
\hline Sample & $\mathbf{1}$ & $\mathbf{1 A}$ & $\mathbf{2}$ & $\mathbf{2 A}$ & $\mathbf{3}$ & $\mathbf{3 A}$ & $\mathbf{4}$ & $\mathbf{4 A}$ & Total \\
\hline Excellent & 3 & 8 & 15 & 22 & 7 & 21 & 3 & 31 & $\mathbf{1 1 0}$ \\
Very good & 17 & 41 & 40 & 57 & 28 & 60 & 36 & 76 & $\mathbf{3 5 5}$ \\
Good & 44 & 73 & 55 & 89 & 63 & 70 & 41 & 59 & $\mathbf{4 9 4}$ \\
Neutral & 62 & 67 & 33 & 66 & 37 & 53 & 31 & 60 & $\mathbf{4 0 9}$ \\
Bad & 64 & 40 & 65 & 31 & 53 & 24 & 65 & 26 & $\mathbf{3 6 8}$ \\
Very bad & 52 & 26 & 43 & 11 & 50 & 12 & 48 & 20 & $\mathbf{2 6 2}$ \\
Disgusting & 30 & 16 & 30 & 4 & 39 & 6 & 52 & 9 & $\mathbf{1 8 6}$ \\
\hline Total & $\mathbf{2 7 2}$ & $\mathbf{2 7 1}$ & $\mathbf{2 8 1}$ & $\mathbf{2 8 0}$ & $\mathbf{2 7 7}$ & $\mathbf{2 4 6}$ & $\mathbf{2 7 6}$ & $\mathbf{2 8 1}$ & $\mathbf{2 1 8 4}$ \\
\hline
\end{tabular}

Table 5. Multiple regression, a model concerning effect of group, respondent ID, gender and field of interest (archaeologist, biologist, others) onto acorn samples taste evaluation counted separately for each acorn biscuit sample. NS for non significant effect of given factor.

\begin{tabular}{ccccc}
\hline Sample/Variable & Group & Respondent & Sex & Professional specialization \\
\hline 1 & $\mathrm{~ns}$ & $\mathrm{~ns}$ & $\mathrm{~ns}$ & 0.0081 \\
2 & 0.0046 & $<0.0001$ & $\mathrm{~ns}$ & $\mathrm{~ns}$ \\
3 & 0.0234 & $\mathrm{~ns}$ & $\mathrm{~ns}$ & $\mathrm{~ns}$ \\
4 & 0.0325 & $<0.0001$ & 0.0097 & $\mathrm{~ns}$ \\
$1 \mathrm{~A}$ & $\mathrm{~ns}$ & $<0.0001$ & $\mathrm{~ns}$ & 0.0156 \\
$2 \mathrm{~A}$ & $\mathrm{~ns}$ & $\mathrm{~ns}$ & $\mathrm{~ns}$ & $\mathrm{~ns}$ \\
$3 \mathrm{~A}$ & $\mathrm{~ns}$ & $\mathrm{~ns}$ & 0.0074 & $\mathrm{~ns}$ \\
$4 \mathrm{~A}$ & $\mathrm{~ns}$ & 0.0128 & $\mathrm{~ns}$ & $\mathrm{~ns}$ \\
\hline
\end{tabular}



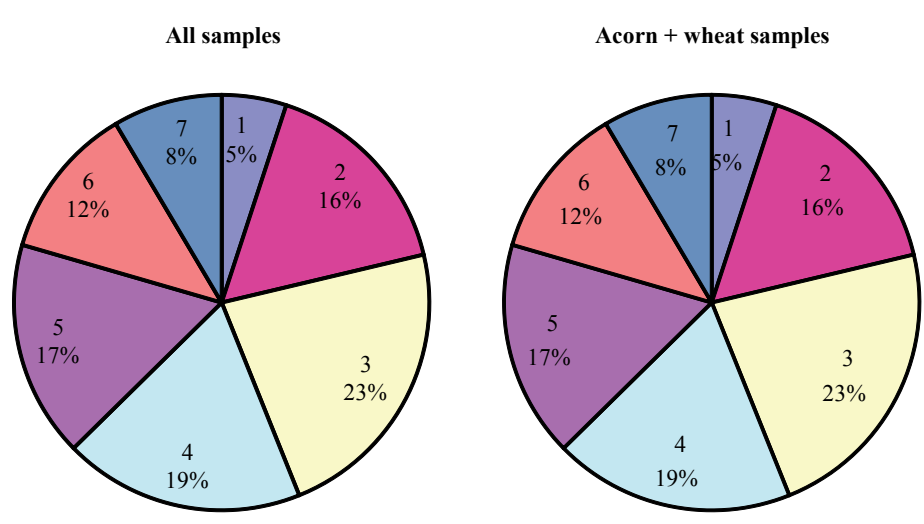

Sample 1

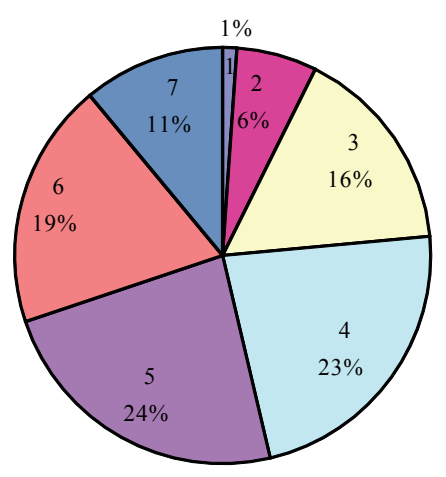

Sample 2A

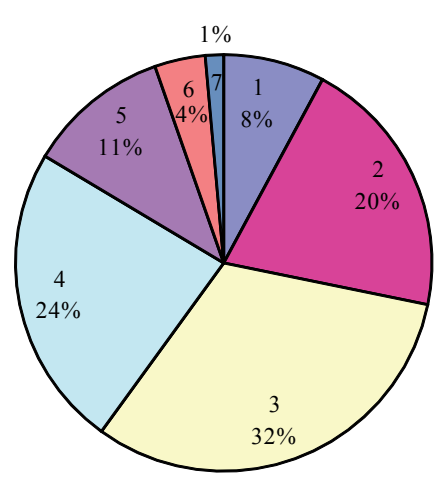

Sample 4

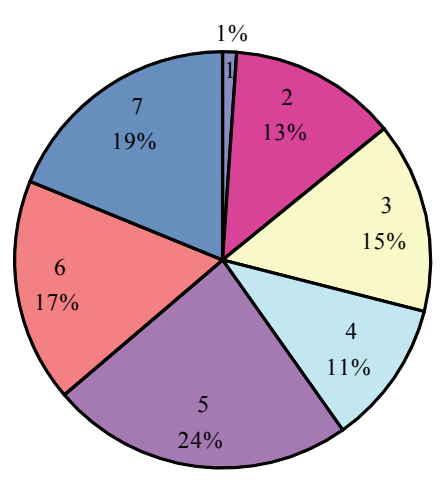

Sample 1A

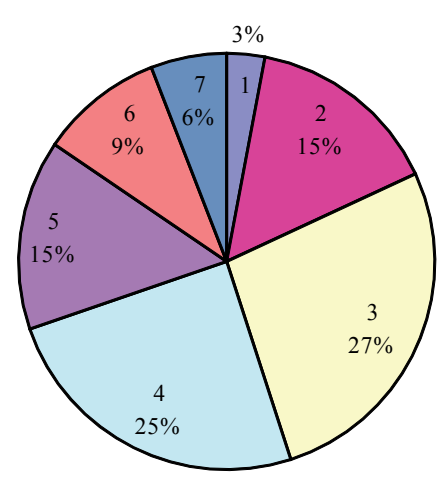

Sample 3

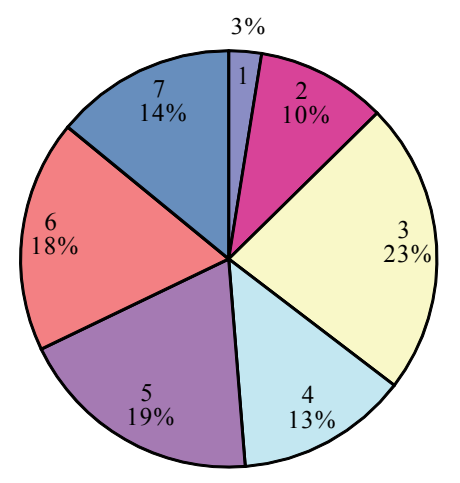

Sample 4A

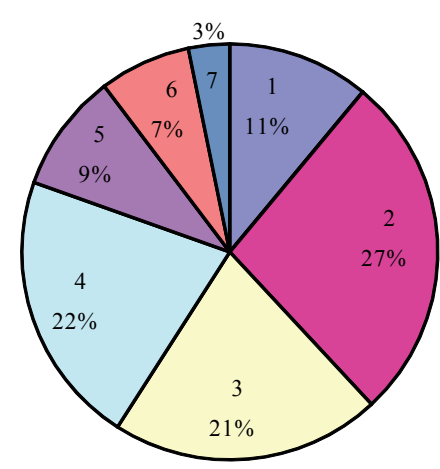

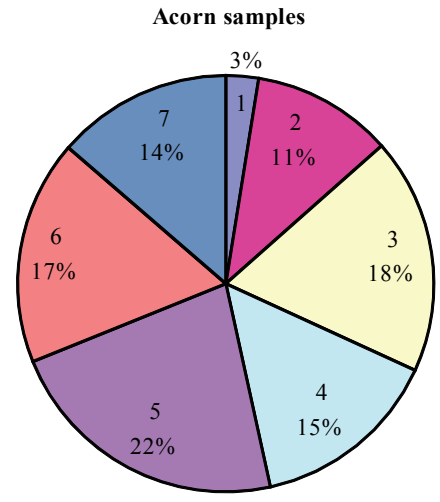

Sample 2

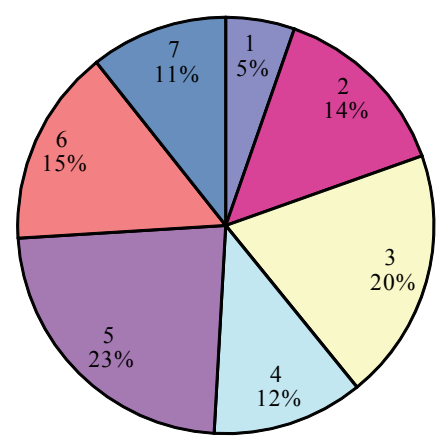

Sample 3A
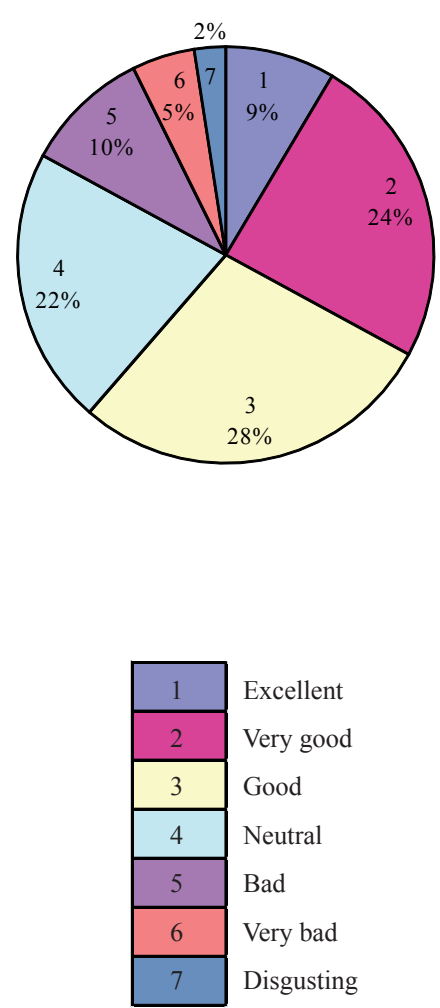

Figure 3. Pie charts depicting total taste scores differences among samples pooled for each individual sample, all pure acorn samples, wheat added samples and all samples (counted from all data). 
Figure 4. Biscuit samples.

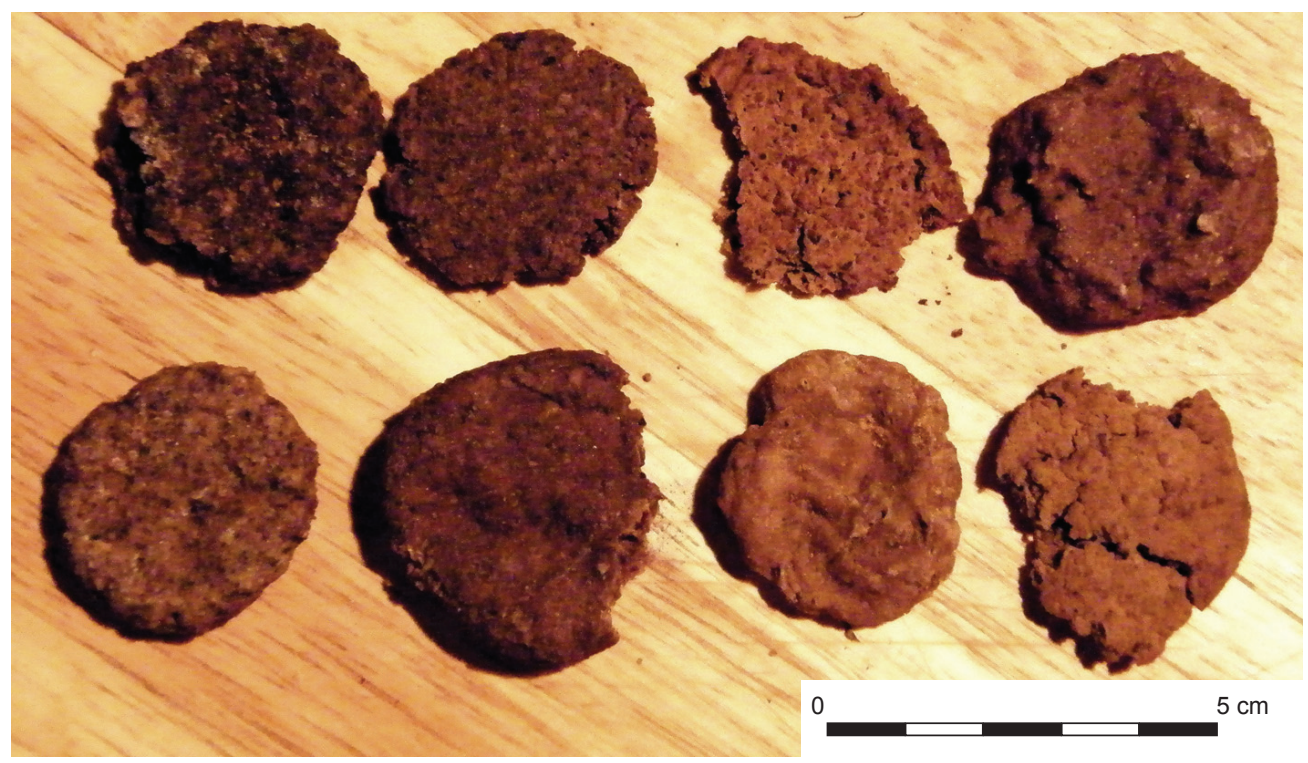

Pure acorn biscuits were rated, from best to worst, 2, 3, 4 and 1 . Acorn/wheat biscuits were rated in slightly different order, from best to worse: 4A, 3A, 2A and 1A. Results show that preparation procedure 1 (both samples 1 and $1 \mathrm{~A}$ ) was evaluated as the least tasty in both categories. As predicted, samples with added wheat flour were rated as tastier overall. Among those samples 4A was rated the tastiest (Figure 2).

To summarize, samples with added wheat flour differ significantly from purely acorn ones (see Table $3, \mathrm{p}<0.001$ ). Surprisingly purely acorn samples do not differ significantly from each other according to preparation procedure. However variation in taste according to different preparation procedures occurs after the addition of wheat flour. Particularly, preparation procedure 1 (both samples 1 and $1 \mathrm{~A}$, no matter whether without or after the addition of wheat flour) differs from other procedures and is evaluated as less tasty. Moreover wheatflour added sample 1A is close to the taste of purely acorn sample 2, which can be seen in Table 3 (difference between samples $1 \mathrm{~A}$ and 2 is not statistically significant, $\mathrm{p}>0.05$ ).

\subsection{Effects of respondent, gender, field of interest and place of acorn collection on observed taste differences}

Each sample was tested separately due to significant differences in the taste of individual samples. A multiple regression model "sample taste $\sim$ group $^{1}+$ respondent + sex + field of interest" revealed that the rating of individual samples corresponds to characteristics of the testers. There is high variability between testers; being highly significant in $50 \%$ of the cases (see Table 5). Acorn source and baker was significant in 37.5\%. Gender and field of study was significant in $25 \%$ of cases. Proportion of explained variability ranges ranges between 4.88 and $17.3 \%$ among different acorn biscuit samples. The best fit of the model was observed in sample 1A. None of the explanatory variables, on the other hand, was significant in explaining taste differences in sample $2 \mathrm{~A}$.

${ }^{1}$ Group is defined as acorn colloection site and experimentator.

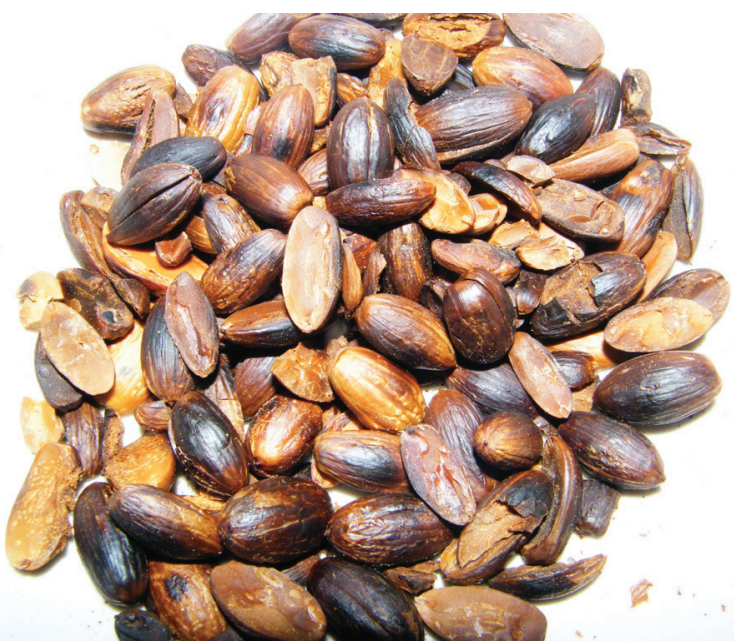

Figure 5. Roasted acorns

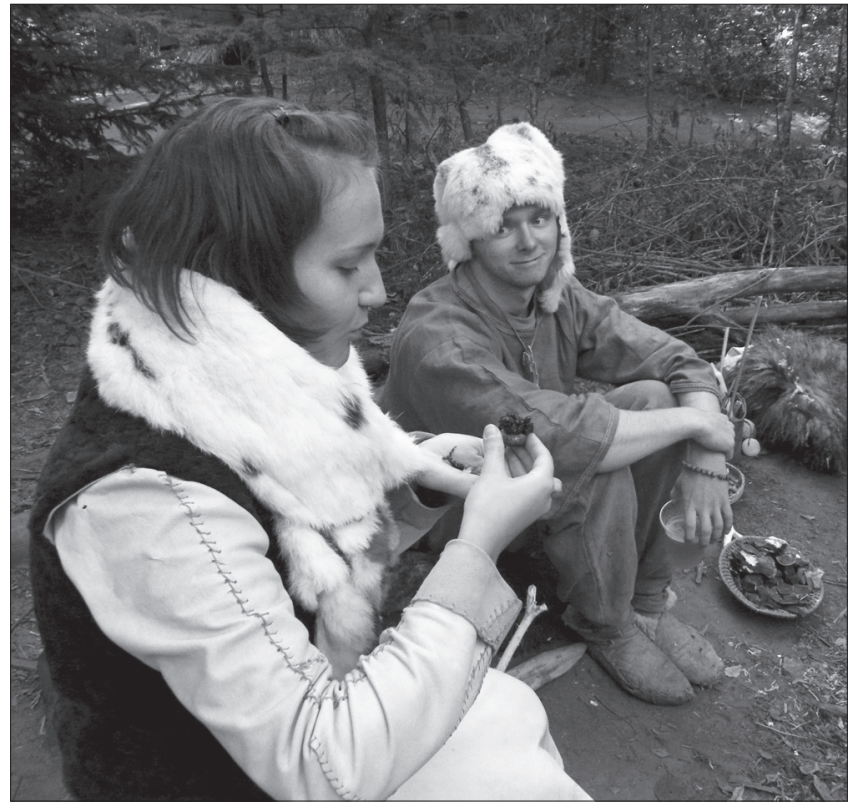

Figure 6. Eating of experimentally prepared biscuits. 


\section{Discussion and conclusions}

Though acorns are considered to be unattractive as a food resource, previous studies have clearly demonstrated that acorns were very likely used as a food resource throughout prehistory (see Part 1.3 of this paper). The present study brings a new perspective on the acorn as a food.

Our experiment found no substantial difference in the taste of pure acorn products, by preparation method (the way in which tannin is removed) On the other hand, not surprisingly, that taste of pure acorn products differed significantly from those with added wheat flour. This may be caused by the fact that tasters are used to the taste of wheat, contrary to acorns. Adding wheat flour likely mitigated the acorn taste and the mixed flour products were consequently thought tastier.

We should also consider the fact that samples 1 and $1 \mathrm{~A}$ have been evaluated as least tasty. This clearly suggests that the procedure (shelling, grinding and subsequent roasting of acorn flour) resulted in a less tasty product than other procedures. This result could indicate that the procedure failed to remove the tannins. Consequently, this preparation method appears unsuitable, in comparison to others used in the experiment.

Tasting results of the remaining samples varied depending upon the addition of wheat flour, acorn source, and the respondent (gender, field of study). According to these results it is reasonable to assume that the final taste of acorn products may not have played a crucial role in the choice of preparation method. Rather, the amount of time, labour and energy invested in the procedure could have been of greater importance.

It is worth considering the variability in results found in relation to acorn source and tester. Since oak trees are tolerant to many different conditions, it seems that taste differs in relation to various environmental conditions under which oaks grow. In addition, some variability could be also explained by minor baking differences of the individual experimentators.

In summary, this paper clearly shows that modern humans are able to consume acorns after proper preparation. The statistical evaluation of test data shows that pure acorn products were rated between 4 and 5 on a scale of 1 (excellent) to 7 (disgusting). Interestingly, a common commercially available Czech rye wheat bread was evaluated as 4 on the same scale, by select testers.

Taking into account that acorns are nutritionally comparable to cereals, the results support the hypothesis that acorns could have been a human staple, particularly in the preagricultural period. On the other hand, there are some factors limiting the possible exploitation of acorns (see Part 1.2), including the amount of work involved in acorn preparation. These are of interest and will be the subject of authors' further investigations.

\section{Acknowledgement}

We are extremely grateful to Dr. Sabine Karg and Dr. Mirosław Makohonienko for their critical reading and helpful remarks upon earlier version of this paper. We also thank Dr. Jaromír Beneš and the Laboratory of archaeobotany and paleoecology, University of South Bohemia, České Budějovice for support. We would like to express our appreciation to everyone who participated in the experiment. We would particularly like to thank Lucie Ambrožová, Jiří Bumerl, Tereza Hausteinová, Monika Hrušková, Jitka Kosňovská, Tomáš Kuneš, Hana Mácová, Eliška Maršálková, Martin Pták and Blanka Slabochová. We are also indebted to the Institute of Prehistory; Adam Mackiewicz University, Poznań. The work was supported by a grant from the Faculty of Science, University of South Bohemia (MSMT 6007665801 \& GAJU 138/2010/P).

\section{References}

AURA, J. E., CARRIÓN, Y., ESTRELlES, E., PERÉZ, G. 2005: Plant economy of hunter-gatherer groups at the end of the last Ice Age: Plant macroremains from the cave of Santa Maira (Alacant, Spain) ca. 120009000 BP. Vegetation History and Archaeobotany 14, 542-550.

BOUBY, L., LEROY, F., CAROZZA, L. 1999: Food plants from Late Bronze Age lagoon sites in Languedoc, southern France: Reconstruction of farming economy and environment. Vegetation History and Archaeobotany 8, 53-69.

CUNNINGHAM, P. 2011: Caching your savings? The use of small-scale storage in European prehistory. Journal of Anthropological Archaeology $30,135-144$.

DE HINGH, A. E. 2000: Food production and food procurement in the Bronze Age and Early Iron Age (2000-500 BC). Ph.D. thesis. Deposited: Faculty of Archeology, Leiden University, Leiden.

DEFORCE, K., BASTIAENS, J., VAN CALSTER, H., VANHOUTTE, S. 2009: Iron Age acorns from Boezinge (Belgium): The role of acorn consumption in Prehistory. Archäologisches Korrespondenzblatt 39, 381-392.

DENNEL, R.W. 1979: The economic importance of plant resources represented on archaeological sites. Journal of Archaeological Science 3, 229-247.

DRESLEROVÁ, D., HORÁČEK, I., POKORNÝ, P. 2007: Př́rodní prostředí Čech a jeho vývoj. In: Kuna, M. (Ed.): Archeologie pravěkých Čech 1. Pravéký svét a jeho poznání. Institute of Archaeology of the Academy of Sciences of the Czech Republic, Praha, 23-50.

GOREN-INBAR, N., SHARON, G., MELAMED, Y., KISLEV, M. 2002: Nuts, nut cracking, and pitted stones at Gesher Benot Ya'aqov, Israel. Proceedings of the National Academy of Science 99, 2455-2460.

GREENBERG, C. H. 2000: Individual variation in acorn production by five species of southern Appalachian oaks. Forest Ecology and Management 132, 199-210.

KARG, S., HAAS, J. N. 1996: Indizien für den Gebrauch von mitteleuropäischen Eicheln als prähistorische Nahrungsressource. Tübinger Monographien zur Urgeschichte 11, 429-435.

KISLEV, M. E., NADEL, D., CARMI, I. 1992: Epipalaeolithic (19000 BP) cereal and fruit diet at Ohalo II, Sea of Galiee, Izrael. Review of Palaeobotany and Palynology 73, 161-166.

KUBIAK-MARTENS, L. 1999: The plant food component of the diet at the Late Mesolithic (Ertebølle) settlement at Tybrind Vig, Denmark. Vegetation History and Archaeobotany 8, 117-127.

KUNEŠ, P. 2008: Human-driven and natural vegetation changes of the last glacial and early Holocene. Ph.D. thesis. Deposited: Charles University, Praha.

LE GOFF, J. 1991: Kultura středověké Evropy. Odeon, Praha.

LEV, E. 2002: Reconstructed materia medica of the Medieval and Ottoman al-Sham. Journal of Ethnopharmacology 80, 167-179.

LEV, E., AMAR, Z. 2000: Ethnopharmacological survey of traditional drugs sold in Israel at the end of the 20th century. Journal of Ethnopharmacology 72, 191-205.

LEV, E., KISLEV, M. E., BAR-YOSEF, O. 2005: Mousterian vegetal food in Kebara Cave, Mt. Carmel. Journal of Archaeological Science 32, 475-484. 
MASON, S. R. L. 1992: Acorns in human subsistence. Ph.D. thesis Deposited: Institute of Archaeology, University College, London.

MASON, S. R. L. 1995: Acornutopia? Determining the role of acorns in past human subsistence. In: Wilkins, J., Harvey, D., Dobson, M. (Eds.): Food in Antiquity. University of Exeter Press, Exter, 12-24.

MASON, S. R. L. 2000: Fire and Mesolithic subsistence - managing oaks for acorns in northwest Europe? Palaeogeography, Palaeoclimatology, Palaeoecology 164, 139-150.

POKORNÝ, P. 2004: Postglacial vegetation distribution in the Czech Republic and its relationship to settlement zones: Review. In: Gojda M. (Ed.): Ancient landscape, settlement dynamics and non-destructive archaeology. Academia, Praha, 395-414

RAKIĆ, S., POVRENOVIĆ, D., TEŠEVIĆ, V., SIMIĆ, M., MALETIĆ, R. 2006: Oak acorn, polyphenols and antioxidant activity in functional food. Journal of Food Engineering 74, 416-423.
ROSENBERG, D. 2008: The possible use of acorns in past economies of the Southern Levant: A staple food or a negligible food source? Levant 40, 167-175.

VENCL, S. 1985: Žaludy jako potravina. K poznání významu sběru pro výživu v pravěku. Archeologické rozhledy 37, 516-565.

VENCL, S. 1996: Acorns as food: again. Památky Archeologické 87, 95111.

ZVELEBIL, M. 1994: Plant use in the Mesolithic and its role in the transition to farming. Proceedings of the Prehistoric Society 60, 35-74. 
